Discussion Paper No. 04-76

\title{
Tax Incentives and the Location of FDI: Evidence from a Panel of German Multinationals
}

Thiess Büttner and Martin Ruf

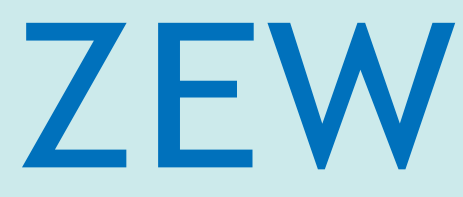

Zentrum für Europäische Wirtschaftsforschung $\mathrm{GmbH}$ Centre for European Economic Research 
Discussion Paper No. 04-76

\title{
Tax Incentives and the Location of FDI: Evidence from a Panel of German Multinationals
}

\author{
Thiess Büttner and Martin Ruf
}

Download this ZEW Discussion Paper from our ftp server:

ftp://ftp.zew.de/pub/zew-docs/dp/dp0476.pdf

Die Discussion Papers dienen einer möglichst schnellen Verbreitung von neueren Forschungsarbeiten des ZEW. Die Beiträge liegen in alleiniger Verantwortung der Autoren und stellen nicht notwendigerweise die Meinung des ZEW dar.

Discussion Papers are intended to make results of ZEW research promptly available to other economists in order to encourage discussion and suggestions for revisions. The authors are solely responsible for the contents which do not necessarily represent the opinion of the ZEW. 


\title{
Tax Incentives and the Location of FDI: Evidence from a Panel of German Multinationals
}

\author{
Thiess Buettner ${ }^{\dagger \ddagger}$ \\ ZEW and Mannheim University
}

Martin Ruf

Mannheim University and University Louis Pasteur, Strasbourg

November 2004

\begin{abstract}
Using a firm-level dataset this paper investigates the impact of taxation on the decision of German multinationals to hold direct investments in other European countries or abroad. Controlling for firm-specific differences in the valuation of potential locations, the results confirm significant effects of tax incentives, market size, and of labor cost on cross-border location decisions. In accordance with Devereux and Griffith (1998) we find that the marginal tax rate has no predictive power for location decisions whereas effective average and statutory tax rates exert significant effects. In particular, the statutory tax rate has strong predictive power for the likelihood of direct investment holdings at a location. The results indicate that an increase in the statutory tax rate by 10 percentage points reduces the odds of observing some positive direct investment by approximately $20 \%$.
\end{abstract}

\footnotetext{
${ }^{\dagger}$ Address: ZEW

L7, 1

Phone: $\quad+496211235160$

D-68161 Mannheim

Fax:

+496211235223

Germany

E-mail: buettner@zew.de
}

${ }^{\ddagger}$ We are grateful to the Deutsche Bundesbank for granting access to the FDI database, Fred Ramb and Heinz Herrmann for their support, to Alfons Weichenrieder, Beatrix Stejskal-Passler, and seminar participants at a Bundesbank workshop for helpful comments. All errors are, however, our own. 


\section{Nontechnical Summary}

Initiated by the study of Hartman (1984) several empirical studies have investigated the influence of taxes on cross-border investments of multinational firms. However, in most studies the focus is on the level of investment and its distribution rather than on the underlying location decisions. An exception is the seminal contribution by Devereux and Griffith (1998) who establish the significance of the effective average tax rate for the choice of location of subsidiaries within Europe using firm-level data for U.S. enterprises. The scarcity of evidence on the impact of taxation on location decisions might be due to the fact that the corresponding analysis cannot be done using aggregate FDI data, but requires data on individual cross-border investments, which are usually difficult to obtain. Only recently the Bundesbank has made available for research its micro-level dataset for foreign direct investment, which offers interesting opportunities to study international location decisions (see Lipponer, 2003 , for a description of the dataset). The aim of the current paper is to use this new and promising dataset in order to study empirically the location decisions of German multinationals. More specifically, the paper investigates the impact of taxation on the decision of German multinationals to hold a foreign direct investment at a specific location. Furthermore, as questionnaires among executives emphasize the significance of statutory tax rates as compared to effective tax rates (Sørensen, 1992), the predictive power of alternative indicators of taxing incentives is tested.

Controlling for firm-specific differences in the valuation of potential locations, the results confirm significant effects not only of the local tax burden but also of market size and labor cost on cross-border location decisions. In accordance with Devereux and Griffith (1998) the marginal tax rate is shown to have no 
predictive power for location decisions whereas effective average and statutory tax rates exert significant effects. In particular, the statutory tax rate has a strong predictive power for the likelihood of direct investment holdings at a location. The results indicate that an increase in the statutory tax rate by 10 percentage points reduces the odds of observing some direct investment by approximately $20 \%$. With regard to the labor cost variable the estimated impact suggests that an increase in the labor cost by 10 U.S. $\$$ reduces the odds of some direct investment by about $30 \%$.

In order to test whether the more advanced degree of integration within the EU shows up in an increased sensitivity to tax incentives, separate estimations have been carried out for the European Union countries. While the results point to an increased sensitivity of location decisions with regard to market size and labor cost, however, the tax incentives show effects similar to those in the complete sample. 


\section{Introduction}

Initiated by the study of Hartman (1984) several empirical studies have investigated the influence of taxes on foreign direct investment (surveys are provided by Hines, 1997, 1999, and de Mooij and Ederveen, 2003). However, in most studies the focus is on the volume and distribution of FDI rather than on the underlying location decisions. One notable exception is Bartik (1985) who shows that the corporate tax rate has a significant impact on business location decisions within the U.S. A more recent study is Devereux and Griffith (1998) who establish the significance of the effective average tax rate for the choice of location of subsidiaries within Europe using firm-level data for U.S. enterprises.

The scarcity of evidence on the impact of taxation on location decisions might be due to the fact that the corresponding analysis cannot be done using aggregate FDI data, but requires data on individual cross-border direct investments, which are usually difficult to obtain. Only recently the Bundesbank has made available for research its micro-level dataset for foreign direct investment, which offers interesting opportunities to study international location decisions (see Lipponer, 2003). The aim of this paper is to use this new and promising dataset in order to study empirically the location decisions of German multinationals. More specifically, the paper investigates the impact of taxation on the decision of German multinationals to hold a direct investment at a specific foreign location. Furthermore, as questionnaires among executives emphasize the significance of statutory tax rates as compared to effective tax rates (e.g., Sørensen, 1992), the predictive power of alternative indicators of taxing incentives is tested.

Exploiting the panel-data features of the dataset in order to control for firm- 
specific differences in the valuation of potential locations, the results confirm significant effects of labor cost, market size, and tax incentives on international cross-border location decisions. In accordance with Devereux and Griffith (1998) we find that the marginal tax rate has no predictive power for location decisions whereas effective average and statutory tax rates exert strong effects.

The next section lays out the investigation approach. This is followed by a short description of the data set. Another section presents the empirical results, before a final section draws some conclusions.

\section{Investigation Approach}

Consider the location decision for the affiliate of a German multinational indexed by $k$. With some positive probability $p_{i, k}$ this affiliate will be placed at location $i$. In the standard view of tax competition location choice is regarded as an increasing function of expected profits, which in turn are determined by taxes $\tau_{i}$ and other local conditions $\mathbf{x}_{i}$. If the choice set is large this can be formalized as

$$
p_{i, k}=f\left(\pi_{k}\left(\tau_{i}, \mathbf{x}_{i}\right)\right),
$$

where $\mathbf{x}_{i}$ is a vector of local characteristics and $\pi_{k}$ represents expected profits in the view of firm $k$. The current investigation basically employs a sample of multinationals in order to estimate a linearized version of this relationship

$$
p_{i, k}=\mathbf{y}_{k} \alpha+\tau_{i} \beta+\gamma_{i}+\mathbf{x}_{i} \delta+\epsilon_{i, k}
$$

where $\epsilon_{i, k}$ is a residual variable. Note that in this simple specification firmspecific effects, as captured by $\mathbf{y}_{k} \alpha$, are assumed to be orthogonal to the loca- 
tion characteristics, as captured by $\tau_{i} \beta+\gamma_{i}+\mathbf{x}_{i} \delta$. However, despite this simplification, the pure cross-sectional tax effect $\beta$ is basically unidentified since the impact of taxes and of known characteristics $\mathbf{x}_{i}$ is already encompassed by the location-specific or country effects $\gamma_{i}$. But, if one is willing to assume that unobserved local determinants of location choice are time-invariant, and if there is some variation in tax incentives over time, a possible solution is to pool observations for different periods and to estimate the tax equation using panel data. Accordingly, the empirical analysis might be concerned with the relationship

$$
p_{i, k, t}=\mathbf{y}_{k} \alpha+\tau_{i, t} \beta+\gamma_{i}+\mathbf{x}_{i, t} \delta+\phi_{t}+\epsilon_{i, k, t},
$$

where $\phi_{t}$ is a time-specific effect. Note that the panel data structure considered here is the pooling of investment decisions across countries and time. Given the assumption that firm effects are orthogonal to location as well as time effects, in this setting the presence of firm-level panel data only helps to control for some differences between companies and to solve aggregation problems but not to discriminate taxation effects from unknown location characteristics.

However, given the availability of firm-level panel data, the assumption that firm effects are orthogonal to location effects is overly restrictive. An alternative approach would allow for firm-specific location effects. Intuitively, this approach would assume that each firm has some idiosyncratic valuation of locations. Identification of tax and other locational characteristics is then only possible using the variation of those characteristics over time within each firmlocation cell. Formally, estimation would then require to allow for a full set of 
firm-location or firm-country effects $\gamma_{i, k}$

$$
p_{i, k, t}=\mathbf{y}_{k} \alpha+\tau_{i, t} \beta+\gamma_{i, k}+\mathbf{x}_{i, t} \delta+\phi_{t}+\epsilon_{i, k, t} .
$$

In principle, standard panel data estimation techniques might be used to estimate this relationship. But, the inclusion of individual effects is not straightforward in the current setting due to the binary nature of the observed dependent variable (firm $k$ either holds an investment at $i$ or not). Some firms will hold an investment at a specific location during all periods; other firms will not hold an investment at this location in any period. Thus, firm-specific location effects will perfectly predict the outcome in these two cases. As a consequence, appropriate estimators such as the fixed-effects logit approach proposed by Chamberlain (1984) focus on a firm's investment in a country only if we observe some changes in location decisions over time.

\section{Dataset}

The empirical analysis basically uses the micro database for FDI provided by the German Bundesbank. This is a comprehensive annual database of direct investment positions of German enterprises held abroad as well as of direct investment positions held in Germany by foreign companies. A favorable characteristic of the dataset is the possibility to trace the direct investment positions of individual firms over time. In its current version, firm-level panel data are available for the period 1996 to 2001.

The collection of the data is enforced by German law, which determines report- 
ing mandates for certain international transactions. ${ }^{1}$ With regard to outward FDI, each German enterprise has to report its foreign assets, provided asset holdings are above some threshold level. In the year 2000 some 8,500 domestic investors returned reports on their foreign direct investment. In 2000 in the case of minority participations (greater $10 \%$ and lower $50 \%$ ) reporting is mandatory if the balance sheet total of the direct investment exceeds 5 million euros; in the case of majority participations, direct investments have to be reported if their balance sheet total is above 0.5 million euro. The database also contains indirect FDI relations, which must be reported if a direct investment enterprise held by a majority participation holds $10 \%$ or more of another enterprise.

A problem with the data is that threshold levels vary over time (see Lipponer, 2003). More specifically, as compared to the year 2000 in the considered time period they tend to be lower in previous years. In order to make sure that the results are not subject to some bias originating in the resulting panel attrition, the current study consistently employs a uniform threshold level at which observations are included in the sample. Hence, direct investments are only included if the current investment position is above the threshold following the definition for the year $2000 .^{2}$

Tax incentives are captured by statutory, effective marginal, and effective average tax rates on investment in the corporate sector of the host country taken from Devereux, Griffith, and Klemm (2002). Note that Germany usually exempts earnings of German affiliates abroad. Hence, the tax burden at the location of the affiliate is decisive from the point of view of German com-

\footnotetext{
${ }^{1} \S 26$ Aussenwirtschaftsgesetz (Law on Foreign Trade and Payments) in connection with Aussenwirtschaftsverordnung (Foreign Trade and Payment Regulations).

${ }^{2}$ While the uniformity of threshold levels across years proved important, note that variations in the definition of the threshold level have been found to have only minor effects on the estimation results.
} 
panies. Given the short time period of the analysis most of other potential location characteristics are probably captured by country effects. However, presumably time-variant location conditions such as market sizes and labor cost are captured by OECD data on GDP and hourly labor cost as provided by the Bureau of Labor Statistics at the U.S. Department of Labor.

For our purposes we exclude FDI in the financial sector, since we are basically interested in the tax effects on real investment decisions. We also exclude direct investments, which are made in branches or partnerships, since in such cases other effective or statutory tax rates apply as in the corporate sector.

Table (1) provides descriptive statistics of the dataset. Note that the number of observations reflects the whole set of possible locations for each enterprize. More specifically, for each company in the dataset in a given year there are 15 separate observations indicating whether or not a positive foreign direct investment is held separately for each of the countries considered.

\section{Results}

As discussed above the empirical analysis of location decisions involves the estimation of location probabilities depending on location and firm characteristics. The logarithm of GDP is used as a proxy variable for the size of the foreign market, the logarithm of hourly compensation of employees in manufacturing is used as an indicator of labor cost. As it is very difficult to account for other locational conditions like public services or agglomeration effects we also include dummy variables for each country in the sample in order to control for unobserved country characteristics. In order to further reduce the consequences of heterogeneity in the sample on the results, we include dummy-variables for 
Table 1: Descriptive Statistics

\begin{tabular}{lrrrr}
\hline \hline Variable & Mean & Std.Dev. & Min. & Max. \\
\hline Statutory tax rate & .347 & .084 & .100 & .532 \\
Effective marginal tax rate & .224 & .071 & .066 & .403 \\
Effective average tax rate & .295 & .074 & .084 & .469 \\
GDP & 1304.9 & 2221.9 & 70.31 & 10020 \\
Labor cost in manuf. & 16.76 & 5.21 & 4.54 & 27.2 \\
Legal status of mother & & & & \\
Sole proprietor/partnership & .185 & .388 & 0 & 1 \\
Stock corporation (AG, KGaA) & .113 & .317 & 0 & 1 \\
Limited liability corporation (GmbH) & .482 & .500 & 0 & 1 \\
Other corporations & .219 & .413 & 0 & 1 \\
Dependent branches & .001 & .033 & 0 & 1 \\
Locations of foreign direct investment & & & & \\
France & .334 & .472 & 0 & 1 \\
Netherlands & .180 & .384 & 0 & 1 \\
Italy & .179 & .383 & 0 & 1 \\
United Kingdom & .235 & .424 & 0 & 1 \\
Ireland & .022 & .145 & 0 & 1 \\
Greece & .023 & .149 & 0 & 1 \\
Portugal & .047 & .212 & 0 & 1 \\
Spain & .169 & .374 & 0 & 1 \\
Sweden & .064 & .244 & 0 & 1 \\
Finland & .022 & .148 & 0 & 1 \\
Austria & .238 & .426 & 0 & 1 \\
Belgium & .118 & .322 & 0 & 1 \\
USA & .326 & .469 & 0 & 1 \\
Canada & .072 & .258 & 0 & 1 \\
Japan & .051 & .220 & 0 & 1 \\
\hline
\end{tabular}

424635 observations representing the possible holdings of foreign direct investments at 15 different locations for 7423 firms in the period 1996 to 2001. 
Table 2: Linear Probability Model

\begin{tabular}{|c|c|c|c|}
\hline method & OLS & OLS & OLS \\
\hline Statutory tax rate & $\begin{array}{l}-.051{ }^{\star} \\
(.025)\end{array}$ & & \\
\hline Marginal eff. tax rate & & $\begin{array}{l}-.005 \\
(.014)\end{array}$ & \\
\hline Eff. average tax rate & & & $\begin{array}{l}-.032 \\
(.022)\end{array}$ \\
\hline $\log$ GDP & $\begin{array}{c}.027 \\
(.012)\end{array}$ & $\begin{array}{l}.015 \\
(.011)\end{array}$ & $\begin{array}{c}.024 \\
(.011)\end{array}$ \\
\hline $\log$ Labor cost in manuf. & $\begin{array}{l}.010 \\
(.010)\end{array}$ & $\begin{array}{c}.012 \\
(.009)\end{array}$ & $\begin{array}{c}.011 \\
(.009)\end{array}$ \\
\hline $\begin{array}{l}\text { Companies } \\
\text { Obervations }\end{array}$ & & $\begin{array}{c}7423 \\
424635\end{array}$ & \\
\hline $\mathrm{R}^{2}$ & .1040 & .1040 & .1040 \\
\hline
\end{tabular}

Dummies for country, time, and legal status of mother included. Standard errors (in parentheses) robust against heteroscedasticity and random firm effects. A star denotes significance at the $10 \%$ level.

the legal status of the mother as one of the few available characteristics of the German investor in the dataset, unless we explicitly allow for individual firm-effects in the estimations.

Table (2) shows the results of a basic linear regression of the probability of holding a direct investment in each of 12 major countries of the European Union, in the U.S., in Canada or in Japan, on three different tax measures, namely the effective marginal tax rate (EMTR), the effective average tax rate (EATR, calculated at a rate of return of $10 \%$ ) and the statutory tax rate (STR). In order to avoid the Moulton (1990) problem, standard errors are robust against random firm effects using the usual Huber-White sandwich formula. The three indicators of the tax burden show different results. While the marginal and effective average tax rates prove insignificant, the statutory tax 
rate shows a significant negative impact. However, GDP proves insignificant as well, and labor cost even show an unexpected positive impact. Quantitatively, the estimated impact of the statutory tax rate suggests that an increase of the statutory tax rate by 10 percentage points reduces the probability to observe a foreign direct investment by about 0.51 percentage points: given an average sample probability of 0.13 this is a relative reduction by $4 \%$.

The linear probability model fails to take account of the binary nature of the dependent variable. Making specific assumptions about the probability distribution of the presence of a direct investment conditional on covariates more efficient estimates can be obtained from corresponding non-linear estimators such as probit or logit. Table 3 provides results. The first panel reports results from probit, the second from random-effects probit and the third panel reports results from logit models. All estimates report robust standard errors. Now, both the statutory as well as the effective average tax rate prove significant. With regard to the marginal probability effects, quantitatively, the results on the tax rates are quite similar as in the linear model. However, some estimates confirm the unexpected positive coefficient on the labor cost, while GDP proves insignificant throughout. While the random effects probit estimation shows somewhat weaker results, the logit estimates yield almost identical marginal effects to the probit model.

Given the strong significance of GDP and, partly, of labor cost in other studies of FDI (e.g., Pain, 2003, or Billington, 1999) its insignificance points to the difficulty to distinguish country characteristics from the country-fixed effects. However, as suggested above, the firm-level data allow us to take account of firm-specific valuations of the attractiveness of locations by means of firmspecific country effects. As these effects would perfectly predict decisions if a 
Table 3: Discrete Probability Models

Probit

\begin{tabular}{|c|c|c|c|c|c|c|}
\hline & Coefficient & Slope & Coefficient & Slope & Coefficient & Slope \\
\hline Statutory tax rate & $\begin{array}{l}-.263^{\star} \\
(.109)\end{array}$ & $\begin{array}{l}-.047^{\star} \\
(.019)\end{array}$ & & & & \\
\hline Marginal eff. tax rate & & & $\begin{array}{l}-.043 \\
(.060)\end{array}$ & $\begin{array}{l}-.008 \\
(.011)\end{array}$ & & \\
\hline Eff. average tax rate & & & & & $\begin{array}{l}-.187^{\star} \\
(.101)\end{array}$ & $\begin{array}{l}-.033^{\star} \\
(.018)\end{array}$ \\
\hline $\log$ GDP & $\begin{array}{l}.1933^{\star} \\
(.110)\end{array}$ & $\begin{array}{l}.034 \\
(.020)\end{array}$ & $\begin{array}{l}.130 \\
(.113)\end{array}$ & $\begin{array}{l}.023 \\
(.020)\end{array}$ & $\begin{array}{l}.189{ }^{\star} \\
(.114)\end{array}$ & $\begin{array}{l}.034 \text { * } \\
(.020)\end{array}$ \\
\hline log Labor cost in manuf. & $\begin{array}{l}.035 \\
(.040)\end{array}$ & $\begin{array}{l}.006 \\
(.007)\end{array}$ & $\begin{array}{l}.044 \\
(.040)\end{array}$ & $\begin{array}{l}.008 \\
(.007)\end{array}$ & $\begin{array}{l}.042 \\
(.040)\end{array}$ & $\begin{array}{l}.007 \\
(.007)\end{array}$ \\
\hline $\begin{array}{l}\text { Log-Likelihood } \\
\text { Pseudo R }{ }^{2}\end{array}$ & \multicolumn{2}{|c|}{$\begin{array}{c}-147772 \\
.1349\end{array}$} & \multicolumn{2}{|c|}{$\begin{array}{c}-147773 \\
.1349\end{array}$} & \multicolumn{2}{|c|}{$\begin{array}{c}-147772 \\
.1349\end{array}$} \\
\hline
\end{tabular}

Dummies for country, time, and legal status of mother included. Standard errors (in parentheses) robust against heteroscedasticity and random firm effects.

Probit with Random Effects

\begin{tabular}{|c|c|c|c|c|c|c|}
\hline & Coefficient & Slope & Coefficient & Slope & Coefficient & Slope \\
\hline Statutory tax rate & $\begin{array}{l}-.307^{\star} \\
(.162)\end{array}$ & $\begin{array}{l}-.042 \text { 夫 } \\
(.022)\end{array}$ & & & & \\
\hline Marginal eff. tax rate & & & $\begin{array}{l}-.050 \\
(.101)\end{array}$ & $\begin{array}{l}-.007 \\
(.014)\end{array}$ & & \\
\hline Eff. average tax rate & & & & & $\begin{array}{l}-.220 \\
(.153)\end{array}$ & $\begin{array}{l}-.030 \\
(.021)\end{array}$ \\
\hline $\log$ GDP & $\begin{array}{l}.225 \\
(.150)\end{array}$ & $\begin{array}{l}.031 \\
(.020)\end{array}$ & $\begin{array}{l}.153 \\
(.155)\end{array}$ & $\begin{array}{l}.021 \\
(.021)\end{array}$ & $\begin{array}{c}.223 \\
(.157)\end{array}$ & $\begin{array}{l}-.030 \\
(.021)\end{array}$ \\
\hline log Labor cost in manuf & $\begin{array}{l}.041 \\
(.050)\end{array}$ & $\begin{array}{l}.006 \\
(.007)\end{array}$ & $\begin{array}{l}.050 \\
(.049)\end{array}$ & $\begin{array}{l}.007 \text { * } \\
(.007)\end{array}$ & $\begin{array}{l}.048 \\
(.049)\end{array}$ & $\begin{array}{l}.007 \text { * } \\
(.007)\end{array}$ \\
\hline Log-Likelihood & -134 & & -134 & & -134 & \\
\hline
\end{tabular}

Dummies for country and time included. Standard errors (in parentheses).

Logit

\begin{tabular}{|c|c|c|c|c|c|c|}
\hline & Coefficient & Slope & Coefficient & Slope & Coefficient & Slope \\
\hline Statutory tax rate & $\begin{array}{l}-.482^{\star} \\
(.193)\end{array}$ & $\begin{array}{l}-.0422^{\star} \\
(.017)\end{array}$ & & & & \\
\hline Marginal eff. tax rate & & & $\begin{array}{l}-.108 \\
(.105)\end{array}$ & $\begin{array}{l}-.009 \\
(.009)\end{array}$ & & \\
\hline Eff. average tax rate & & & & & $\begin{array}{l}-.377^{\star} \\
(.180)\end{array}$ & $\begin{array}{l}-.033 \text { * } \\
(.016)\end{array}$ \\
\hline $\log$ GDP & $\begin{array}{l}.4022^{\star} \\
(.222)\end{array}$ & $\begin{array}{l}.035 \\
(.019)\end{array}$ & $\begin{array}{l}.301 \\
(.229)\end{array}$ & $\begin{array}{l}.026 \\
(.020)\end{array}$ & $\begin{array}{l}.421 \\
(.231)\end{array}$ & $\begin{array}{l}.037^{\star} \\
(.020)\end{array}$ \\
\hline log Labor cost in manuf. & $\begin{array}{l}.077 \\
(.073)\end{array}$ & $\begin{array}{l}.007 \\
(.006)\end{array}$ & $\begin{array}{l}.091 \\
(.073)\end{array}$ & $\begin{array}{l}.008 \\
(.006)\end{array}$ & $\begin{array}{l}.088 \\
(.073)\end{array}$ & $\begin{array}{l}.008 \text { * } \\
(.006)\end{array}$ \\
\hline $\begin{array}{l}\text { Log-Likelihood } \\
\text { Pseudo R }{ }^{2}\end{array}$ & \multicolumn{2}{|c|}{$\begin{array}{c}-147872 \\
.1343\end{array}$} & \multicolumn{2}{|c|}{$\begin{array}{c}-147874 \\
.1343\end{array}$} & \multicolumn{2}{|c|}{$\begin{array}{c}-147873 \\
.1343\end{array}$} \\
\hline
\end{tabular}

Dummies for country, time, and legal status of mother included. Standard errors (in parentheses) robust against heteroscedasticity and random firm effects. 
Table 4: Linear Probability Model with Firm-Specific Country Effects

\begin{tabular}{l|lll}
\hline \hline method & OLS-FE & OLS-FE & OLS-FE \\
\hline Statutory tax rate & $-.479^{\star}$ & & \\
Marginal eff. tax rate & $(.187)$ & & \\
& & -.019 & \\
Eff. average tax rate & & & \\
& & & $-.118)$ \\
log GDP & $.339{ }^{\star}$ & .175 & .315 \\
& $(.188)$ & $(.193)$ & $(.196)$ \\
log Labor cost in manuf. & $-.125^{\star}$ & $-.111^{\star}$ & $-.113^{\star}$ \\
& $(.059)$ & $(.058)$ & $(.059)$ \\
\hline Firm country cells & \multicolumn{3}{|c}{4789} \\
Obervations & \multicolumn{3}{|c}{24528} \\
Hausman fixed vs. random & $40.0(8)$ & $33.1(8)$ & $35.8(8)$ \\
\hline
\end{tabular}

Estimation with fixed effects for each firm-country cell. Time-specific effects included. Standard errors (in parentheses).

firm holds a direct investment or does not hold any direct investments during the whole reporting period at a specific location, we restrict attention to those observations where a change in the location decision for each firm-country cell is observed at least once in the period analyzed. Table 4 provides results from a corresponding linear probability model allowing for firm-specific country effects. Note first that the number of observations is drastically reduced which reflects the removal of all observations where a direct investment position is or is not observed for a firm in the total time period considered. This is reflected in a much higher average sample probability to observe a direct investment of about 0.51 . While statutory and effective average tax rates show significant negative effects the marginal effective tax rate, again, proves insignificant. The GDP now shows significant positive effects and the labor cost variable no longer shows the unexpected positive sign but shows a significant negative effect. 
Quantitatively, the estimated impact of the statutory tax rate seems much larger than in the previous estimations suggesting that an increase of the statutory tax rate by 10 percentage points reduces the probability to observe a direct investment by about 4.8 percentage points. Given the higher sample probability to observe a direct investment, the relative reduction in the probability is about $9.4 \%$ which is roughly twice as large than in the basic estimations. Also the impact of the effective average tax rate is increased: an increase by 10 percentage points reduces the probability to observe a direct investment by $5.9 \%$. Despite of its smaller coefficient, the standard error of the effective average tax rate is not much smaller, indicating that the estimate is less precise. However, it has to be noted that the EATR assumes a specific rate of return, which may not be representative for all location decisions or all firms in general. Thus, the smaller coefficient is likely indicative of a measurement error problem. With regard to the labor cost the results from the first specification using the statutory tax rate indicate that a doubling of the labor cost reduces the probability to observe a direct investment by 12.5 percentage points. Evaluated at the mean level of labor cost in the sample of 16.8 U.S. $\$$ per hour, this indicates that an increase in the labor cost by 10 U.S. $\$$ would result in a relative reduction of the location probability by about $14.6 \%$.

Now, the linear probability model neglects the presence of a qualitative dependent variable. Table 5 reports results from the fixed-effects logit model. Qualitatively, the results confirm the findings from the linear model. The signs of the coefficients are the same, and also the significance against zero effects is confirmed. The interpretation is, however, slightly different, as the coefficients report the impact on the log odds ratio. Hence, an increase of the statutory tax rate by 10 percentage points reduces the odds of an investment 
Table 5: Discrete Probability Model with Firm-Specific Country Effects

\begin{tabular}{l|lll}
\hline \hline method & Logit-FE & Logit-FE & Logit-FE \\
\hline Statutory tax rate & $-1.98^{\star}$ & & \\
Marginal eff. tax rate & $(.764)$ & & \\
& & -.074 & \\
Eff. average tax rate & & $(.479)$ & $-1.25^{\star}$ \\
& & & $(.724)$ \\
log GDP & $1.41{ }^{\star}$ & .735 & 1.31 \\
& $(.775)$ & $(.798)$ & $(.809)$ \\
log Labor cost in manuf. & $-.516^{\star}$ & $-.457 \star$ & $-.468 \star$ \\
& $(.241)$ & $(.240)$ & $(.240)$ \\
\hline Firm country cells & & 4789 & \\
Obervations & & 24528 & \\
Log-Likelihood & -9638 & -9641 & -9639 \\
\hline
\end{tabular}

Estimation with fixed effects for each firm-country cell. Time-specific effects included. Standard errors (in parentheses).

by about $20 \%$. With regard to the labor cost we find that doubling the labor cost reduces the odds by about $50 \%$. In terms of the above example of an increase in the labor cost by 10 US $\$$ the odds would fall by about $30 \%$.

The 15 countries selected are quite heterogenous, including EU member states as well as - from a German perspective - rather distant locations such as U.S., Canada, and Japan. It seems quite likely that tax incentives and other locational conditions have a different impact at least for these two subsets of countries. Table 6 reports results only for the location decision within the EU. As compared to the estimations for the full sample, while the tax rate effects are similar, the sensitivity with regard to GDP and labor cost is increased. However, partly reflecting the smaller sample the standard errors are increased as well. 
Table 6: Discrete Probability Model with Firm-Specific Country Effects, EU countries only

\begin{tabular}{l|lll}
\hline \hline method & Logit-FE & Logit-FE & Logit-FE \\
\hline Statutory tax rate & $-1.94^{\star}$ & & \\
Marginal eff. tax rate & $(.793)$ & & \\
& & -.053 & \\
Eff. average tax rate & & $(.486)$ & \\
& & & -1.17 \\
log GDP & $1.54^{\star}$ & 1.01 & $(.741)$ \\
& $(.890)$ & $(.938)$ & $(.932)$ \\
log Labor cost in manuf. & $-.785^{\star}$ & $-.706^{\star}$ & $-.735^{\star}$ \\
& $(.332)$ & $(.329)$ & $(.330)$ \\
\hline Firm country cells & & 3896 & \\
Obervations & & 19907 & \\
Log-Likelihood & -7822 & -7825 & -7824 \\
\hline
\end{tabular}

Estimation with fixed effects for each firm-country cell. Time-specific effects included. Standard errors (in parentheses). 


\section{Conclusions}

The aim of the paper is to test empirically the influence of taxation on the decision of German multinationals to hold a foreign direct investment at a specific location. In difference to most of the literature this paper uses a firm-level dataset to study location decisions. While this raises difficulties in combining data at the firm as well as at the country level, it enhances possibilities to identify tax incentives relative to other possibly unknown country characteristics. Furthermore, as questionnaires among executives emphasize the significance of statutory tax rates as compared to effective tax rates, the predictive power of alternative indicators of taxing incentives is tested.

The analysis first of all documents the difficulties to identify tax incentives and other locational characteristics against simple location or country effects. While supporting an impact of the statutory tax rate, basic regressions yield mixed and partly unexpected results for control variables such as labor cost and GDP even if the non-linearities arising from the binary dependent variable are taken into account. Only when allowing for firm-specific valuation of a country's attractiveness, significant effects can be established not only for statutory tax rates but also for the effective average tax rate, the market size, as captured by the GDP, and the labor cost. The results indicate that an increase in the statutory tax rate by 10 percentage points reduces the odds to observe some positive direct investment by approximately $20 \%$; for the effective average tax rate the corresponding figure is $12.5 \%$. With regard to the labor cost variable the estimated impact suggests that an increase in the labor cost by 10 U.S. $\$$ per hour reduces the odds of observing an investment by about $30 \%$. 
In conditioning on firm-specific country effects the sample is, however, considerably reduced and attention is focused on those multinationals which are revealed to alter their location decisions in the six-year period considered. Thus, the stronger results for this sub-sample are likely caused by a larger fraction of footloose industries and, in this respect, may not be representative for all German multinationals.

In order to test whether the more advanced degree of integration within the EU shows up in an increased sensitivity to tax incentives, separate estimations have been carried out for the European Union countries. While the results point to an increased sensitivity of location decisions with regard to market size and labor cost, however, the tax incentives show effects similar to those in the complete sample.

Among the different indicators of tax incentives, the statutory tax rate has the strongest predictive power and yields the strongest effects. In contrast, the marginal effective tax rate is not significant at all. Given the significance of the effective average tax rate this is in accordance with Devereux and Griffith (1998) who argue that the effective average rather than the marginal tax rate matters for location decisions. However, one could speculate whether the weaker predictive power of the effective average tax rate as compared to the statutory tax rate may indicate that uncertainties in the rate of return or in the applicability of certain deductions lead investors to rely on the statutory tax rate. But it also could simply reflect differences in the rate of return of investment projects which might give rise to a measurement error problem. 


\section{Datasources and Definitions}

Firm-level data are taken from the micro-dataset of the Bundesbank, see Lipponer (2003) for an overview.

GDP in U.S. Dollars, nominal. Source: OECD.

Hourly compensation of workers: Hourly compensation costs in U.S. Dollars for production workers in manufacturing. Source: U.S. Bureau of Labor Statistics.

Tax incentives are taken from Devereux, Griffith, and Klemm (2002). The data are kindly provided by the authors at the IFS website.

\section{References}

Bartik, T. J. (1985), Business location decisions in the United States : estimates of the effects of unionization taxes, and other characteristics of states, Journal of Business \&5 Economic Statistics 3, 14-22

Billington, N. (1999), The location of foreign direct investment: an empirical analysis, Applied Economics 31, 65-76

Chamberlain, G. (1984), Panel data, in: Griliches, Z., and M. D. Intriligator, (eds.), Handbook of Economcetrics II, Amsterdam et al., 1247-1318

Devereux, M. and R. Griffith (1998), Taxes and the location of production evidence from a panel of US multinationals, Journal of Public Economics $68,335-367$

Devereux, M., Griffith, R. and A. Klemm (2002), Corporate income tax reforms and international tax competition, Economic policy 02, 451-495

De Mooij, R. and S. Ederveen (2003), Taxation and foreign direct investment: a synthesis of empirical research, International Tax and Public Finance $10,673-693$

Hartman, D. G. (1984), Tax policy and foreign direct investment in the United States, National Tax Journal 37, 475-488 
Hines, J. (1997), Tax policy and the activities of multinational corporations, in: Auerbach, A. J., (ed.), Fiscal Policy: Lessons from Economic Research, Cambridge et al., 401-445

Hines, J. (1999), Lessons from behavioral response to international taxation, National Tax Journal 52, 305-322

Lipponer, A. (2003), A "new" micro database for German FDI, in: Herrmann, H. and R. Lipsey, Foreign Direct Investment in the Real and Financial Sector of Industrial Countries, Berlin et al. 215-244

Moulton, B. R. (1990), An illustration of a pitfall in estimating the effects of aggregate variables on micro units, Review of Economics and Statistics $72,334-338$

Pain, N. (2003), Fiscal policies, european integration and structural changes, in: Herrmann, H. and R. Lipsey, (eds.), Foreign Direct Investment in the Real and Financial Sector of Industrial Countries, Berlin et al., 99-136

Sørensen, P.B. (1992), The effects of taxation on international investment and economic efficiency, in EC Commission, (ed.), Report of the Commitee of Independent Experts on Company Taxation, Luxembourg, 313-358 